\title{
CORPORATE ENTREPRENEURSHIP AS A FACTOR OF COMPETITIVENESS OF COMPANIES
}

\author{
Miloš Golubović \\ Ekonomski Fakultet Niš, \\ Univerzitet u Nišu, Srbija \\ milos.golubovic19@gmail.com \\ Gordan Janković \\ Ekonomski Fakultet Niš, \\ Univerzitet u Nišu, Srbija \\ jankovic.gordan90@gmail.com
}

\begin{abstract}
Apstrakt
The purpose of the research of this paper is to conduct an analysis of the impact of corporate entrepreneurship on the business performance of a modern enterprise in the conditions of global competition. The research goal is to show through the comprehensive approach the significance of this interdependence, further expand the existing knowledge base and suggest to organizations to turn to this entrepreneurial model in order to achieve a higher degree of flexibility and innovation. Scientific methods of induction, deduction, comparison, analysis, and synthesis used in the research unambiguously indicate that the application of corporate entrepreneurship simultaneously contributes to the improvement of the business results of both individuals within the organization and the organization themselves, leading ultimately to a better market positioning of enterprises. Corporate entrepreneurship encourages employees to take an individual initiative, thus creating a perfect ground for doing new innovations that are the only guarantee of survival in a dynamic market XXI century.
\end{abstract}

Ključne riječi: corporate entrepreneurship, competitiveness, innovation.

\section{KORPORATIVNO PREDUZETNIŠTVO KAO FAKTOR KONKURENTNOSTI PREDUZEĆA}

\begin{abstract}
Svrha istraživanja ovog rada je sprovođenje analize uticaja korporativnog preduzetništva na poslovne performanse savremenog preduzeća u uslovima globalne konkurencije. Istraživački cilj je da se kroz sveobuhvatni pristup ukaže na značaj navedene međuzavistnosti , dodatno proširi postojeća baza znanja i sugeriše organizacijama okretanje ka ovom modelu preduzetništva u cilju višeg stepena fleksibilnosti i inovativnosti. Naučne metode indukcija, dedukcija, komparacija, anliza i sinteza korišćene u istraživanju nedvosmisleno pokazuju da primena korporativnog preduzetništva istovremeno doprinosi unapređenju poslovnih rezultata kako pojedinaca unutar organizacije, tako i same organizacije, a što u krajnjoj instanci vodi ka boljem tržišnom pozicioniranju preduzeća. Korporativno preduzetništvo podstiče zaposlene na individualno preuzimanje inicijative, a time se stvara pogodno tlo za rađanje novih inovacija koje su jedina garancija opstanka na dinamičnom tržištu 21. stoleća.
\end{abstract}

Keywords: korporativno preduzetništvo, konkurentnost, inovacije JEL codes: L10 


\section{INTRODUCTION}

Economic globalization as a key social trend of the modern era has greatly changed the business environment of the modern enterprise. The growing interdependence of the world economy around and interplanetary competition in the single, global market put entrepreneurship on the pedestal of economic discussion. In economic theory, there is no single definition of entrepreneurship, as various authors entrepreneurship have observed from different angles, and accordingly, highlighting some of its characteristics, have come to different conclusions. However, what is common in all modern definitions of entrepreneurship and what can be taken as indisputable fact is that entrepreneurship should be based on the initiative, the management of social and economic mechanisms and resources for practical purposes as well as the acceptance of contemporary business conditions that require a willingness to take risks and failure (Shapero, 1975). The modern entrepreneur must constantly search for the opportunity offered by the market, develop strategies to use the best given circumstance, provide all the necessary resources for the implementation of the chosen strategy, and manage the company in an optimal way. By such an approach, an entrepreneur achieves a better market position and profit, but at the same time reduces the risk of becoming a victim of the natural selection market. The primary challenge for entrepreneur XXI century is how to outsmart the competition and how to develop faster than others. So the company becomes more flexible to the dynamic changes in their environment, and which are beyond its reach (Dean, Brown and Bamford, 1998).

Business traditional type are faced with the pressure change in business organizations work more than ever in its history. On the one hand, they are forced into conditions of high competition hire the highest quality and most capable work force offered by the market, while on the other hand they still strive for the strict implementation of established procedures and rules of business, with clearly expressed hierarchy and inflexibility on changes in the environment. The problem arises because individuals who are aware of their creative abilities and quality have a strong need to assume greater responsibility, but therefore a greater freedom for their ideas. If their aspiration remained unfulfilled, the logical consequence of the frustration of the creative individual. In this case, the company would first face the decline in productivity of its work, and later, most often, by going to another organization in which it would achieve its affinities. In this way, the most skilled personnel are lost, and with them also goes their ideas that somebody else will turn into innovation. Such companies can not achieve the desired results in the long term and are gradually being eliminated from the market. Precisely in this field arises the need for corporate entrepreneurship. Corporate entrepreneurship basically represents the creating of an entrepreneurial spirit within an already existing organization. According to Antončić, corporate entrepreneurship is based on new business ventures, innovativeness, selfsustainability and pro-activity of enterprises, and the synergy of these activities is overcome by the shortcomings of traditional entrepreneurship (Antončić and Hisrich, 2001). As the process, a corporate enterprise is characterized by a high degree of dynamics and complexity, and is based on a series of motivational, drivers, cognitive and structural assumptions with the resulting need for its further investigation. A large number of researchers believe that corporate entrepreneurship, despite its strong 
contribution to the improvement of business operations, it is still not enough general (Hornsby et al., 2009) and further research efforts should be directed towards its heterogeneous nature and dimensions (Phan et al., 2010). That is precisely the main reason for a new research in this field.

\section{THE NATURE AND SPECIFICS OF CORPORATE ENTREPRENEURSHIP}

The roots of corporate entrepreneurship dating back to the period of affirmation of the capitalist system of economic trends. Corporate entrepreneurship is has evolved over time, a full boom. has been experienced in the era of a unified liberalized market and globalization. The very process of its development was based on the needs of the company to respond to the current problems with adequate organizational changes and to achieve a more favorable position compared to the competition. According to Porter, competitive advantage of a company is based on a combination of activities that will accomplish the distance in relation to its competitors in the eyes of consumers (1996). Therefore, today, the corporate entrepreneurship seen as an effort to increase the competitive advantage of an organization through innovation that will significantly change the balance in the field of its competitiveness within existing industries or create completely new industries (Ferreira, 2002). A special focus is on the activities of entrepreneurs, since in the final instance they will depend on the achieved results of the business (Covin and Miles, 1999).

The global economic crisis of 2008 was re-actualized the issue of entrepreneurial transformation. Faced with a drastic fall in demand in the market, companies have faced a new challenge which is improving their competitiveness and further prosperity in the circumstances. Such a challenge can resist only companies that have sufficient internal capacity to work through individuals or teams within an organization come to innovation, changes in the existing organization or establishing entirely new organizational structure of the business. According to professor Avlijaš, corporate enterprise represents introduction entrepreneurial spirit in the existing organization in order to overcome the repulsion towards flexibility, growth and diversification of operations (2013). From all this previously mentioned it can be concluded that the activities in the field of corporate governance can help the organization to dictate changes in the market in which it operates, or that they eventually adjust (Kuratko, 2009). According to Ginsberg, corporate entrepreneurship allows the company to develop new business within existing organizations, but at the same time provides the opportunity to revitalize the organization through auditing internal values (1990).

In practice there are two types of events in the corporate enterprise. The first type is based on the creation of a corporate enterprise, and the other on strategic entrepreneurship (Morris, Kuratko and Covin, 2008). Creating a corporate venture includes the expansion of the company's business portfolio, the introduction of enterprise which had not existed in its scope of work. The new venture can arise as a result of the company's aspiration to realize new competencies, by adding related business activities or by investing in ex-ventures that already exist. Strategic entrepreneurship is a strategic entrepreneurial initiative that can, but does not have to 
lead to a new business venture, which includes the following strategic approaches (Morris, Kuratko and Covin, 2008):

- $\quad$ strategic renewal,

- $\quad$ sustainable regeneration

- redefining the business domain,

- organizational revitalization,

- $\quad$ restructuring of the business model.

Figure 1: Impact of corporative strategy to implement knowledge

\begin{tabular}{|c|c|c|c|}
\hline $\begin{array}{l}\text { Strategies of } \\
\text { corporate } \\
\text { entrepreneurs } \\
\text { hip }\end{array}$ & $\begin{array}{l}\text { Organization } \\
\text { al } \\
\text { revitalization }\end{array}$ & $\begin{array}{l}\text { Types of new } \\
\text { knowledge }\end{array}$ & $\begin{array}{c}\text { Implementati } \\
\text { on of } \\
\text { knowledge } \\
\text { through } \\
\text { corporate } \\
\text { entrepreneurs } \\
\text { hin }\end{array}$ \\
\hline $\begin{array}{c}\text { Strategic } \\
\text { reconstructio } \\
\mathrm{n} \\
\text { Sustainable } \\
\text { regeneration } \\
\text { Redefining } \\
\text { business } \\
\text { domain } \\
\text { Organization } \\
\text { al } \\
\text { revitalization } \\
\text { Restructuring } \\
\text { of business } \\
\text { model } \\
\text { Corporate } \\
\text { venture }\end{array}$ & $\begin{array}{l}\text { Acquisitive } \\
\text { learning } \\
\text { Experimental } \\
\text { learning }\end{array}$ & $\begin{array}{l}\text { Technical } \\
\text { Integrative } \\
\text { Exploatitive }\end{array}$ & $\begin{array}{c}\text { Application } \\
\text { of } \\
\text { knowledge- } \\
\text { extension of } \\
\text { production } \\
\text { lines } \\
\text { Combining } \\
\text { and } \\
\text { expanding } \\
\text { knowledge - } \\
\text { developing a } \\
\text { new platform } \\
\text { Applying } \\
\text { new } \\
\text { knowledge to } \\
\text { value } \\
\text { creation - } \\
\text { creating a } \\
\text { new venture }\end{array}$ \\
\hline
\end{tabular}

Source: Dess, Ireland, Zahra, Floyd, Janney \& Lane, 2003, p. 354

Strategic renewal is based on changing the fundamental values of the organization, which should lead to a substantial shift in its operations. It replaces the existing system with a completely new value system, and the ultimate goal is better positioning in the market. Sustainable regeneration is a strategic approach that basically has continuous changes in business resulting from the organization's constant aspirations to align business with market demands. Although these changes are far from radical, consumers will observe and evaluate them when forming their own preferences. Redefining the business domain involves the proactive performance of the organization, where, through a new product or even a completely new market, there is a real distinction in relation to competition. Organizational revitalization aims to change internal processes, capacity and structure, while business strategy remains unchanged. With this approach, the organization does not interfere with the existing value system, nor does it extend the product range, but the accent is on innovations within the business process that should contribute to better achieving the defined goal. 
Restructuring a business model is a strategic approach that should lead to greater operational efficiency of an organization's business through the change of an existing business model. This change should facilitate the company's business, but also to reduce costs through increased efficiency. A typical representative of this strategic approach in modern business is "outsourcing". By a comparative analysis of traditional and modern corporate entrepreneurship, key differences that exist between them can be seen. While traditional entrepreneurship requires the dominant entrepreneur (usually the owner of the company) to take over all the burden of innovative activities and business organization of enterprises, in the case of corporate entrepreneurship, the goal is for the entire organization to behave in the spirit of entrepreneurship, and the synergy of individual creativity translates into business results. According to a survey conducted in 2010. In the year, there are 12 key segments where their differentiation can be noticed. The results of this research are presented in Table 1.

Table 1: Differences between traditional and contemporary corporate entrepreneurship

\begin{tabular}{|c|c|}
\hline Traditional enterpreneurship & Corporate entrepreneurship \\
\hline Entrepreneur takes risk & The company takes the risk \\
\hline Enterpeneuer owns an innovative idea & The company owns a new concept \\
\hline Enterprenuer is an owner & $\begin{array}{l}\text { A corporate entrepreneur does not have to } \\
\text { have a share in the company, but may have } \\
\text { a smaller percentage of ownership }\end{array}$ \\
\hline $\begin{array}{l}\text { Possible rewards for entrepreneurs are } \\
\text { theoretically unlimited }\end{array}$ & $\begin{array}{l}\text { There are clear limits on the financial profit } \\
\text { that a corporate entrepreneur can achieve }\end{array}$ \\
\hline One wrong step can mean complete failure & $\begin{array}{l}\text { There is more room for possible mistakes, } \\
\text { the company can make a mistake }\end{array}$ \\
\hline $\begin{array}{l}\text { Independence of entrepreneurs, though a } \\
\text { successful entrepreneur usually has strong } \\
\text { team support }\end{array}$ & $\begin{array}{l}\text { The interdependence of the idea creator } \\
\text { with other team members, there is a } \\
\text { possibility that a corporate entrepreneur } \\
\text { must share credit for an idea with a larger } \\
\text { number of people }\end{array}$ \\
\hline $\begin{array}{l}\text { Flexibility in changing directions and } \\
\text { experimenting }\end{array}$ & $\begin{array}{c}\text { Rules, procedures and bureaucracy limit } \\
\text { the ability of a corporate entrepreneur to } \\
\text { maneuver }\end{array}$ \\
\hline Speed of decision making & Longer approval cycles \\
\hline Little security & Job security and benefits packages \\
\hline $\begin{array}{c}\text { Ograničen obim poduhvata koji se } \\
\text { može pokrenuti }\end{array}$ & $\begin{array}{l}\text { A wide network of contacts that can further } \\
\text { enhance the idea }\end{array}$ \\
\hline $\begin{array}{l}\text { Limited scope of enterprise that is can start } \\
\text { up }\end{array}$ & $\begin{array}{l}\text { Possibility for relatively fast launch of } \\
\text { significant enterprises of a wider scope }\end{array}$ \\
\hline Significant resource constraints & $\begin{array}{l}\text { Access to finance, research and } \\
\text { development, production facilities, } \\
\text { organized sales staff; built brand, } \\
\text { developed distribution channels, existing } \\
\text { databases and market research sources; } \\
\text { established customer base }\end{array}$ \\
\hline
\end{tabular}

Source: Morris M., Entrepreneurship \& Innovation, 2010, p. 38 
From Table 1 it can be concluded that the only advantages of traditional compared to corporate entrepreneurship in the speed of decision-making and flexibility. The reason for this should be sought in the inocular nature of decision-making in the traditional entrepreneurship model. Also, in case of a positive outcome, the prize of an independent entrepreneur from the achieved result is theoretically unlimited, unlike the corporate model where the financial compensation is pre-defined. In all other segments, corporate entrepreneurship shows better results. The most important difference between these two models is in the risk taking segment. In the traditional model, the business risk is taken over by the entrepreneur, while the corporate risk model is taken over by the company. Likewise, job security is far greater in the corporate model, as well as the ability to quickly launch a significant enterprise of a wider scope. It is clear that, unlike a traditional entrepreneur, a corporate entrepreneur has at his disposal a wide network of contacts to further advance his idea. It should be added here that large companies with corporate entrepreneurship have better access to the financial market and that they can more easily collect external funds to finance their own ideas. In addition, companies also have greater experience and knowledge from the previous period, which gives them an added advantage in the perception of the final outcome.

\section{APPROACH TO CORPORATE ENTREPRENEURSHIP MODERN ENTERPRISE}

Činjenica je da strateško miksiranje biznisa nema zacrtanih granica. Ako granice postoje one se najčešće nalaze u umu zaduženih preduzetnika i top menadžera. Miksiranje o kome smo izlagali u prethodnom tekstu svakako se ne ograničava samo na strategije razvoja firme. Forme i sadržaji miksiranja protežu se i mogu da se protežu na sve domene biznisa sa kojima se firma bavi na određenom tržištu i određenom ambijentu svoga poslovanja. Odnosi se svakako i na umešno kombinovanje marketing, finansijskih, tehnoloških, ekoloških i drugih strategija, kojom prilikom posebno „unakrsna kombinovanja“ mogu iznedriti vrlo maštovita i uspešna poslovna rešenja.

\section{Focused approach}

Focused approach to corporate entrepreneurship separates the activities of that domain from the company's regular activities. The team of corporate entrepreneurs must be separated from other colleagues in the company, and their work is independent of the current portfolio of company activities. This promotes a higher degree of creativeness of their work, and their ideas are obviated by administrative barriers. However, the key problem of this approach arises in the implementation phase of the generated ideas. Given that they were created within a limited circle of creative entrepreneurs, there is a latent danger of their misunderstanding and rejection by other employees of the company. Examples of this approach to corporate entrepreneurship are the 
creation of a special group for new ventures and business incubators (Dess, Lumpkin and Eisner, 2007).

A special group for new ventures is most often formed as an informal group of experts within the company with the aim of identifying and examining potential new business ventures. Meetings within a group are carried out according to an ad hoc principle, ie when a space for a new venture is opened on the market. By contrast, a group of new ventures can be organized as a formalized body within an organization with permanent members and dedicated resources for the realization of new ideas. The key difference between the group for new ventures and traditional research and development departments is the extent of the powers that they possess and the possibility of taking risks for decisions made. Members of the new venture group are increasingly tasked to independently devise a way of financing their activities (including external financing) and establish cooperation with potential investors.

Business incubators, as a model of a focused approach to corporate entrepreneurship, are tasked with assessing a new business venture, providing the necessary resources for its implementation, and providing autonomy and further development of the venture after a certain period of support. During implementing a new venture, support for business incubators is most often seen in the transfer of business premises, infrastructure, knowledge base and information, as well as network contacts. For the "occupants" of the business incubator, the knowledge and experience that it possesses is of particular importance, which the main company can not provide. Nevertheless, it should be noted that membership in a business incubator is not a guarantee of success in itself, as in practice there are examples of some large companies (British Airways, Compaq Computers, Marconi and Vodafone Groups), which despite significant investments invested in business incubators, had to give up these projects (Dess, Lumpkin and Eisner, 2007).

\section{Broad approach}

Broad approach to corporate entrepreneurship can be realized only in companies that entrepreneurial activities are incorporated into the internal system of values and culture of organization it self. Such companies highly value creative initiative entrepreneurial type in their employees, working on preserving and enhancing its organizational culture and are always ready for new ideas and the changes they bring. As initiators of the change, the important role in these companies, besides the employees, are also the external entities - consumers, business partners and members of the wider interest group to which the company itself belongs. Simply, any ideas that can positively affect the company's business results will be accepted.

The key advantage of such an approach to corporate entrepreneurship is reflected in a high degree of flexibility in relation to changes in the environment. Openness to new ideas and ventures gives the company the ability to respond in a timely manner to the chances that the market offers as an exogenous factor. At the same time, the organizational culture that affirms the freedom of the individual within the organization attracts the most capable people from the labor market who want a higher degree of autonomy and responsibility in their work, thus gaining an additional advantage over the competition. Also, the scrupulous approach to corporate 
entrepreneurship provides a higher degree of top management coordination with lower-level managers and employees, where top managers take the role of mentors by giving their knowledge, experiences and contacts, which additionally contribute to the realization of new ideas. Nevertheless, the shortcomings of this approach should also be mentioned here. Excessive openness to innovation can lead to a high dynamic of changes in the organization's business, even in conditions where there are no real needs. Thus, on the one hand, activities within the organization needlessly complicate, and, on the other hand, require the costs related to their research and adaptation.

\section{Models of corporate entrepreneurship}

Modern economic theory has 4 models of corporate entrepreneurship and to: enabling, productive, opportunistic and advocacy model (Wolcott and Lippitz, 2010). The starting point of their segmentation comprises the following criteria:

- ownership of the new venture

- the method of financing the activities of corporate entrepreneurship.

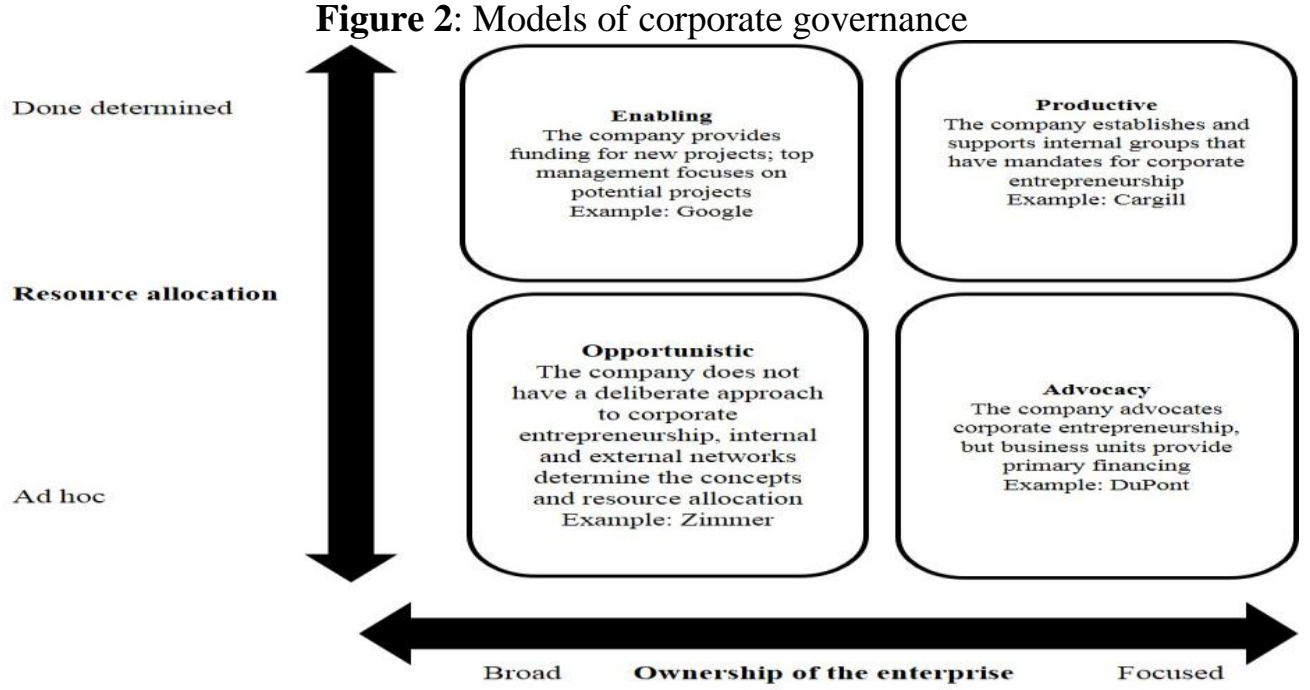

Source: Wolcott R., The Four Models of Corporate Entrepreneurship, 2007 Opportunistic model of corporate entrepreneurship

In the opportunistic model of corporate entrepreneurship, the ownership of a new venture and the financial resources for the realization of the venture are not predefined. Companies which operating under this model have no systematic approach to the development of new business ventures and innovations, but are the result of the work of creative and capable individuals within the organization. Such individuals come to ideas independently by analyzing the possibilities of new ways of creating value for the company through a creative combination of business resources (Avlijaš, 2010). Since new ventures have been created on an ad hoc basis, it is logical 
that the financing of these funds is not provided in advance, and subsequently the ways to obtain the necessary funds.

\section{Allowing model of corporate entrepreneurship}

Unlike the opportunistic model, in the enabling model of corporate entrepreneurship, funding for new ventures has been provided in advance. Companies operating under this model stimulate the entrepreneurial activities of their employees that are in line with the company's business strategy. In such companies it is of particular importance that there are clear and objective criteria on the basis of which potential new ventures will be evaluated. In addition, the role of the company in the process of implementing new ventures is reflected in the provision of guidelines for the use of reserved funds for the purpose of research, support to top management, but also the engagement of additional experts that would facilitate the realization of this venture.

\section{Advocacy model of corporate entrepreneurship}

This model of corporate entrepreneurship is based on a focused ownership of new ventures, with the business units in charge of their implementation providing primary funding. In order to realize the new venture within this model, it is first necessary to establish a special group of employees, headed by someone with undisputable credibility with other employees in the company. Within the group, through various member initiatives, a range of ideas arises and form criteria for their evaluation. After choosing the best alternative, a group with the support of the company's management develops a plan of its realization in order to overcome possible obstacles. At the last stage, it is essential that the manager with other members of the formed group convince managers of other business units within the company about the significance of the realization of the selected enterprise and obtain their consent for the realization. In this way, interest is generated in others for the chosen venture, which is a prerequisite for its successful realization.

\section{Manufacturer's model of corporate entrepreneurship}

Compared to other models, the manufacturer's model of corporate entrepreneurship is characterized by the highest degree of structure and formalism. Operations under this model, the company provides to minimize the risk of wasting resources and establishing optimal cooperation between the various business units within the organization. For the implementation of a new enterprise in the context of this model, it is necessary that both resources and ownership of the new venture are predefined. The new venture is developing outside of regular business activities of the company, and only after proving its profitability can be connected as an equal member of the business portfolio. It should be noted that the realization of new undertakings according to the manufacturer's model and carries certain risks, which also represent the most important limitation in its use (Wolcott and Lippitz, 2007). Therefore, this approach corporate entrepreneurship is recommended only for companies that have substantial financial resources. 


\section{THE IMPORTANCE OF CORPORATE ENTREPRENEURSHIP FOR COMPETITIVE ADVANTAGE - IMPROVING INDIVIDUAL AND ORGANIZATIONAL PERFORMANCE}

Market position and business performance achieved largely depend on the quality of management and the way resources are managed. Given that the resources available to the company are limited, it is necessary to seek to optimize their use. Human capital, as the most important resource of an enterprise, plays a key role in achieving the competitive advantage of the company, and consequently the imperative of efficient human resources management arises. It is precisely in this field that the importance of corporate entrepreneurship should be considered.

There is a special correlation between corporate entrepreneurship and human resource management. Corporate entrepreneurship maximally affirms employees in the process of realizing their tasks, which ensures better effects of human capital. On the other hand, management that is aware of the importance of using the potential of its employees, invests a lot of energy to encourage individuals to take initiatives and risks within the organization, thereby reversing the process of strengthening corporate entrepreneurship within the organizational culture. By integrating corporate entrepreneurship and human resources management, the synergy of their effects is realized, which is reflected both in the improvement of individual and organizational performance.

Figure 3: Correlation of corporate entrepreneurship and human resources and their combined impact on the performance of employees

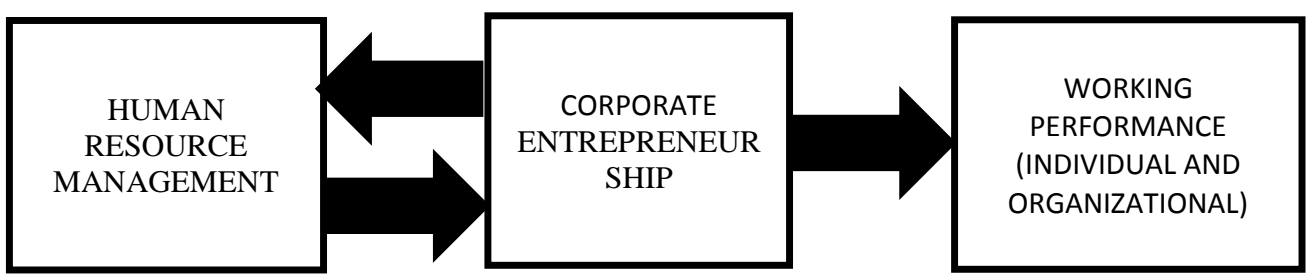

Source: Authors

\section{The impact of corporate entrepreneurship on performance of individuals}

The relationship between the employee's performance and the environment in which he performs his activities can be observed through the prism of the "Social Exchange" (SE) model. In accordance with this model, the two sides within one correlation can achieve their ultimate goal only with the given opposite side. Translated into the field of employee - organization, this would mean a higher degree of freedom to an employee with an adequate compensation for the benefits of his work, while the organization would get a motivated employee who feels a greater degree of responsibility for the decisions he makes (Cropanzano and Mitchell, 2005). By involving the employee in the decision-making process, he has a pronounced psychological effect on the employee, which he personally associates with the 
achieved results of the organization. Achieved success through the venture undertaken, the individual accepts as his own, but also applies to possible mistakes. This makes sense of belonging to the organization gaining importance, and motivation in work and responsibility becomes the main initiators of individual results that ultimately overlap with the performance of the entire organization.

\section{The impact of corporate entrepreneurship on the business performance of the organization}

There are numerous studies dealing with the impact of corporate entrepreneurship on the performance of the company. According to Wood, there are 5 factors that are the guarantor of a successful corporate entrepreneurship that leads to the desired results at the level of the organization, which are (2014):

- support management,

- motivation - compensation package,

- flexible organizational structure,

- availability of resources,

- freedom to work.

In a study that included 400 randomly selected companies from the field of auto parts with particular emphasis on financial efficiency of operations, the authors Lekmat and Selvarajah also confirmed a positive correlation between corporate entrepreneurship and the results achieved. The achieved results are evaluated through increased profitability, cash flow, increased sales and the level of representation in the market. Comparing the trends of these indicators and the level of implementation of corporate entrepreneurship, the authors came to the conclusion that corporate entrepreneurship has a significant, positive impact on the business aspect of the organization financially (Lekmat and Selvarajah, 2008).

Chen was with a group of researchers in a study from 2005 showed that a key role in the development of corporate entrepreneurship in a company has the support of top management. This support is reflected in encouraging employees to make decisions and encourage innovation in the creation (2005). The same opinion is authors Hisrich and Kearney in their work suggest that the company should have made clear the support structure that would enable flexible business turned to innovation (2012). Clark is in his study went a step further by claiming that all companies their existing policies and programs should be reviewed and possibly adjust in order to foster entrepreneurship and innovation activities (2010).

The organizational structure of the company is of particular importance because it defines the division, grouping and mutual coordination of tasks within the company (Robbins, Judge and Campbell, 2010). The conclusion is that companies need to build such organizational structures that will contribute to the strengthening of corporate entrepreneurship in order to maximize the new entrepreneurial chances. On this occasion, a special emphasis should be placed on a higher level of creativity of employees. Thus, one should avoid rigorous restrictions and encourage employees to effectively engage in the design and implementation of innovations. The success of the new organizational structure largely depends on the management awareness of the 
importance of corporate entrepreneurship and their readiness to alleviate the workload of employees in order to strengthen creativity and the inspiration of employees (Othman and Shuaib, 2014).

\section{CONCLUSION}

Little spheres of social life of modern man can boast such a pace as to the economy. The growing trend of globalization, more complex customer requirements, digitization, turbulent geopolitical events affecting the planetary level companies to get out of the traditional business and turned to innovation. In this regard, corporate entrepreneurship markedly gaining in importance. Through this model of entrepreneurship increase the operational performance of individuals, through a synergy effect leads to the improvement of business results of the entire organization. By leaving the initiative in making decisions increasing number of employees are increased chances of inventiveness, that grew into market valorization of innovation. Just to confirm the results of this research. Due to greater participation in the decisionmaking process, employees feel a greater degree of responsibility and motivation for the results achieved. Successful adaptation of corporative largely depends on the willingness of managers to the decision-making process involving all employees, even those with lower levels of the hierarchical structure. In this way, the innovation capacity reaches its optimum point, the entire organization becomes more resistant to exogenous factors of its operations.

Corporate entrepreneurship is no longer a matter of choice but a modern organization condition sine qua non of preserving market position, and very often the question of survival. Faced with the dilemma Innovate or perish economic operators have themselves pave the way market champion. Only judge on the match and the narrator's last words is always the customer, a good competitor to achieve a win philosophy „market in the center of the Universe".

\section{BIBLIOGRAFIJA}

1. Antončić, B., Hisrich, R. D., "Intrapreneurship: Construct Refinement and CrossCultural Validation”, Journal of Business Venturing 16, no. 61, 2001, pp. 495 - 527.

2. Avlijaš R., Preduzetništvo, Beograd, 2010

3. Avlijaš, R., Avlijaš, G., Preduzetništvo, Novi Sad, 2013

4. Chen, J. Zhu, Anquan, W., A Systems Model of Corporate Entrepreneurship. International Journal of Manpower, 2005, pp. 529-543

5. Clark, N. D., Innovation Management in SMEs: Active Innovators in New Zealand. Journal of Small Business and Entrepreneurship. 2010, pp. 601-619

6. Covin J.G., Miles M.P.,: Corporate Entrepreneurship and the Pursuit of Competitive Advantage, Entrepreneurship Theory and Practice, 1999 
7. Cropanzano, R., Mitchell, M.S., Social Exchange Theory: An Interdisciplinary Review. Journal of Management. 2005, pp. 874-900

8. Dean T. J., Brown R. L. \& Bamford C. E., Differences in large and small firm responses to environmental context: strategic implications from a comparative analysis of business formations, Strategic Management Journal, 19: 1998, pp. 709728

9. Dess, G. G., Ireland, R. D., Zahra, S. A., Floyd, S. W., Janney, J. J., \& Lane, P. J., Emerging issues in corporate entrepreneurship. Journal of Management, Vol. 29. no. 3, 2003

10. Dess, G., Lumpkin, G., \& Eisner, A., Strategijski menadžment. Beograd: Data Status, 2007

11. Elfring, T., Corporate Entrepreneurship and Venturing, Springer, 2005, pp. 3

12. Ferreira, J.,: Corporate Entrepreneurship: a Strategic and Structual Perspective, International Council for Small Business, 47th World Conference, 2002

13. Guth, W. D., \& Ginsberg, A., Corporate Entrepreneurship. Strategic Management Journal, Special issue 11, 1990, pp. 5-15

14. Hishrich, R.D., Kearney, C., Corporate Entrepreneurship: How to Create a Thriving Entrepreneurial Spirit Throughout Your Company. McGraw-Hill. New York, 2012

15. Hornsby, J. S., Kuratko, D. F., Shepherd, D. A., \& Bott, J. P., Managers' corporate entrepreneurial actions: Assessing a measurement scale. Journal of Business Venturing , 2009

16. Kuratko, D. F., Entrepreneurship: Theory, process, practice, 8th ed, Mason, OH: Thomson Publishers. Retrieved October 30, 2012

17. Lekmat, L., Selvarajah, C., Corporate Entrepreneurship And Firm Performance: An Empirical Study In Auto Parts Manufacturing Firms In Thailand, 2008

18. Morris, M. H., Kuratko, D. F., \& Covin, J. G., Corporate Entrepreneurship and Innovation. 2nd ed. Mason, Thomson South-Western, 2008

19. Othman, N. H. B., Shuaib, A. S. B., The Relationship between Corporate Entrepreneurship towards Organizational Performance. University Malaysia Kelantan. Malaysia, 2014

20. Phan, P., Wright, M., Ucbasaran, D., \& Tan, W., Corporate entrepreneurship: Current research and future directions. Journal of Business Venturing, 2010

21. Porter, M., What is Strategy, Harvard Business Review, November-December 1996

22. Robbins, S.P., Judge, T.A., Campbell, T.T., Organizacijsko ponašanje. Mate d.o.o. Zagreb, 2010, pp. 536-561

23. Shapero, A., Entrepreneurship and Economic Development, Wisconsin, Project ISEED, LTD, the Center for Venture Management, 1975, pp. 187

24. Wolcott, R., Lippitz, M., The Four Models of Corporate Entrepreneurship, MIT Sloan Management Review, 2007

25. Wolcott, R., Lippitz, M., Grow from Within, Mastering Corporate Entrepreneurship and Innovation, McGraw Hill, New York, 2010

26. Wood, C. C., Hudgens, B. J., Reed, T. S., Perceptions of Corporate Entrepreneurship in Air Force Organizations: Antecedents and Outcomes. Journal of Small Business \& Entrepreneurship, 2014, pp. 117-132 


\section{RESUME}

A brief overview of certain application development strategies, as well as possible ways of their mutual mixing, represents only a small part of the top of the iceberg of real business opportunities, which are opened up in the domain of strategic management in front of ambitious and imaginative entrepreneurs and top managers. Bearing in mind that in the environment of globalized market operations, which today is characterized by exceptional business opportunities, but also with significant business hazards, it is clear that no selected strategic approach to mixing can provide the organization with an unlimited long period of successful business. Sooner or later, each newly created strategic approach is outdated and becomes commercially overestimated. Or, what is often happening in practice, it becomes the subject of discerning competitors, which in practical terms loses the qualities of inventiveness and originality.

The solution in the turbulent and uncertain environment and the context of market business is expressed in the permanent search and implementation of new innovative strategic opportunities that can provide satisfactory results through thought-provoking mixes.

Finally, it should be pointed out at the fact that the process of mixing different business and development strategies is not a one-off procedure, with which the problem is permanently solved by the application of the given procedure. It is about a process of creative thinking and action, which is constantly taking place, as long as there is an organization that carries out a certain market business.

As part of the foregoing, we should not stress in particular that indebted entrepreneurs and top managers should also be adequately strategically educated and informed in order to be able to successfully manage their management tasks related to successful strategic combination. 